The Polish Journal of the Arts and Culture. New Series 13

(1/2021): 213-217 [REVIEW]

DOI: $10.4467 / 24506249$ PJ.21.011.13738

\title{
Minor Mountain Elohim, Feminine Face of Yahweh and Assyrian Apotropaic Fad. Some Remarks on the Margins of: Izaak J. de Hulster, Joel M. LeMon, Image, Text, Exegesis. Iconographic Interpretation and the Hebrew Bible (London: Bloomsbury T\&T Clark, 2015), pp. 336.
}

\section{Wojciech Kosior}

WoJciech Kosion a graduate of Psychology, Religious Studies and Jewish Studies, adjunct at the Centre for Comparative Studies of Civilisations (Jagiellonian University). He is currently working on the Elyonim veTachtonim - an inventory of angels, demons, ghosts and monsters in early rabbinic literature (https:/elyonimvetachtonim. project.uj.edu.pl/).

iD https://orcid.org/0000-0002-1555-5952

E-MAIL: wojciech.kosior@uj.edu.pl 


\section{No graven image (Exodus 20:4)}

The present book is a multi-authored endeavour written by the specialists in various fields such as archaeology, biblical studies, art history, theology, religious studies and linguistics. Their analyses are deeply informed by the recent discoveries in the sphere of the ancient iconography and, as it turns out, the imagery, very ambiguous and multifaceted in itself, can shed additional light on the textual materials. Although this idea might seem rather counterintuitive the editors stress that however one decides to understand the biblical ban on images, the Hebrew Bible [hereinafter: HB] was conceived in the world of visual art. Accordingly, each of the contributors proves that the study of the ancient iconography adds a lot to the interpretation of the Scripture.

The topics tackled in the present dissertation, their broad range notwithstanding, can be divided in several sections. The first group of articles revolves around the broadly understood portrayal of emotions. Brent A. Strawn (The Iconography of Fear: Yir'at Yhwh (יראת יהוה) in Artistic Perspective) analyses the textual evidence and proves that the idea of fear has a broad semantic field. Depending on the context it can express a variety of meanings, ranging from the visceral terror to paternal adoration. In addition to the literary sources, Strawn furnishes rich iconographic material and investigates the poses taken by the human figures. This chapter is inherently tied to the one of Thomas Staubli (Images of Justification) which deals with the images of the supplicant standing before a deity. Taken together they clearly show that the portrayal of the relation between man and god mirrored that of a man and their king and one can only think of the further consequences of this metaphorical reliance. In this regard it is somewhat surprising that neither of the authors made any reference to Rudolph Otto's conception of tremendum et fascinans.

\section{...and you shall see my back, but my face shall not be seen (Exodus 33:23)}

A large cluster of subjects revolves around the portrayal of Yahweh and other supernatural beings with an emphasis put on their hybridity. Michael J. Chan and Maria Metzler (Lions and Leopards and Bears, O My: Re-Reading Isaiah 11:6-9 in Light of Comparative Iconographic and Literary Evidence) go against the popular interpretation of the image drawn by the said Isaian passage. The 
authors offer that the inclusion of the exotic animals to the royal zoos served as an element of public relations. Furthermore, the gathering of wild animals in one place under the royal throne symbolically meant that these were all subdued by the king himself. Thus, one cannot help but wonder whether the garden of Eden should not be construed rather as a tool of highlighting the power of Yahweh rather than apotheosis of peaceful and balanced coexistence of the species. Izaak J. de Hulster (A God of the Mountains? An Iconographic Perspective on the Aramean Argument in 1 Kings 20:23) in turn presents Yahweh as a weather deity in his natural habitat. De Hulster departs from the passage in 1 Kings 20:23 to argue that the preferences of the Aramean soldiers were not due to the military reasons but stemmed from the religious assumption that the battles need to be conducted on the preferred deities' grounds. De Hulster remarks that Yahweh is clearly connected to the mountain landscape and as such should be perceived as one among many deities of this type. Given the subsequent career of Yahweh it is enlightening to have a glimpse at the early stage of his development. Rüdiger Schmitt (Mixed Creatures and the Assyrian Influence on the West Semitic Glyptic Repertoire) acknowledges the hypothesis of the "Assyrian crisis" of Judea and analyses the Western Semitic demonological iconography. He shows that although it drew heavily from the art of the contemporary Mesopotamia, it did not go further than that and these Assyrian imports have most probably been used in apotropaic function without particularly deep analysis of their initial purpose. This chapter as well as the section in toto evokes two thoughts. First, one should remain careful and withhold from deriving too much meaning from the iconographical presentation. Second, it is difficult not to see the similarities with the tattoo and other body-modifications fad which is so prevalent in the modern era.

\section{Blessings of the Breasts and the Womb (Genesis 49:25)}

Definitely the most elaborate and spacious cluster of papers concerns the female imagery. Several authors present what might be called a thesaurus of distinctive traits including the inherent features such as long hair or hourglass figure as well as the body language: stances, gestures and face expressions. A very apt question is addressed by Elizabeth Bloch-Smith (Acculturating Gender Roles: Goddess Images as Conveyors of Culture in Ancient Israel) who wonders whether these figures were actually perceived as erotic. In answering it she distinguishes between a functional nakedness 
and symbolic nudity with the latter signifying the divine qualities. In doing so, Bloch-Smith challenges the tradition that interprets nakedness as symbolising humiliation solely and emphasises the fact that by portraying undressed women their fertility was promoted. Amy Rebecca Gansell (The Iconography of Ideal Female Beauty Represented in the Hebrew Bible and Iron Age Levantine Ivory Sculpture) in turn recovers what might be called the ancient beauty standards. She scrutinises the biblical vocabulary of beauty derived from the roots such as נע ם and, and shows the associated meanings ranging from sexual to intellectual attractiveness. By juxtaposing the biblical vocabulary and metaphors with the iconography she is then able to deliver a tentative list of particularly valuable features such as oversized and outlined eyes, large breasts and slender body - what surprisingly, is not that far away from the modern standards presented by Bloch-Smith.

Two chapters deal specifically with the divine femininity. Jackie Wyse-Rhodes (Finding Asherah: The Goddesses in Text and Image) goes against the assumption of the widespread popularity of Asherah image in the ancient Near East and argues that she may have been standing for female deities in general. Thus, apart from emphasising the metonymical role played by Asherah she also acknowledges the secondary mythopoetic potential of her figure, who is often employed as the modern symbol of female empowerment. Martin Klingbeil in turn ("Children I Have Raised and Brought up" (Isaiah 1:2): Female Metaphors for God in Isaiah and the Iconography of the Syro-Palestinian Goddess Asherah) bases on the previous research which clearly shows that the gods of the HB are construed primarily in the anthropomorphic terms and distinguishes a separate group of female sub-metaphors. These in turn he juxtaposes with the textual and iconographic manifestations of Asherah (going somewhat against the conclusions of Jackie Wyse-Rhodes) using the idea of conceptual metaphor as a common ground. In doing so he explicitly proves the great methodological potential of cognitive linguistics which can be applied in both textual and iconographic studies. It is only after reading this chapter that one cannot help but wonder whether male god described in female qualities might be indicative of some lacking element. From this perspective and if to consider the HB in toto, Yahweh deprived of his female consort, simply had to incorporate some of her features thus turning into a semantic androgyne. 


\section{The ear of the wise seeks knowledge (Proverbs 18:15)}

The remaining cluster of papers revolves around various methodological issues. Meir Lubetski (The Function and Meaning of MY'MN on Hebrew Seals in Light of Accompanying Iconography) studies the problematic inscription found on the Hebrew seals and by comparing it with the Egyptian materials concerning the god Amun sheds some new light on the problem. Meindert Dijkstra (The Ivory Beds and Houses of Samaria in Amos) approaches the role of ivory in various types of artefacts. Hans Ulrich Steymans (The Egyptian Deity Menkeret and Psalm 89 as a Royal Funeral) in an epic attempt analyses a broad range of Egyptian materials so as to come up with new interpretation of Psalm 89 containing the funerary rite witnessing to the role of God as psychopompos. Finally, the book is wrapped up by de Hulster's manual (Appendix. Practical Resources for Iconographic Exegesis) which contains valuable guidelines for those interested in performing this type of research as well as a plethora of exemplary bibliographic references. In fact, the tome itself boasts a large number of photographs and sketches and as such may be used as a very valuable repository. Also, given the swift development of Internet and electronic media, the paragraph dealing with the legal matters may prove particularly helpful.

Finally, one more thing that deserves a special praise is the fact, that all the papers follow the same clear and lucid pattern: the purposes of each endeavour are explicitly listed in the opening section while the concluding remarks summarise the most important implications of the given paper. This makes the text extremely lucid what facilitates the reading despite the variety of individual styles applied in particular chapters. One could only wish for such discipline in other multi-authored works. 